\title{
Eksistensi Unsur Hara Tanah Terhadap Kerentanan Lahan Kritis di Kawasan DAS Alo Kabupaten Gorontalo
}

\author{
Risman Jaya ${ }^{1}$ \\ ${ }^{1}$ Program Studi Geografi, Sains dan Teknologi, Universitas Muhammadiyah Gorontalo \\ Jl. Prof. Dr. H. Mansoer Pateda Desa Pentadio Timur Kab. Gorontalo \\ risraider13@gmail.com
}

\begin{abstract}
Alo watershed is a conservational area which is geographical administrative located in Gorontalo regency which is covering three districts that are district of West Limboto, Tibawa and Pulubala. The research was conducted with the aim to know the existence of nutrients to the condition of the land in the watershed. The method that is used is a field survey to obtain a soil nutrient testing sample and with laboratory testing method using gravimetric assay analysis for water content testing, hydrometer method for soil texture testing, Walkey-Black method for C-Organic testing, Kjeldahl method for Nitrogen testing, Olsen method for $\mathrm{P}_{2} \mathrm{O}_{5}$ testing and Lame Photometer method for $\mathrm{K}_{2} \mathrm{O}$ testing. From all conducted analysis, informations obtained are on sample 1 with the condition of the land is somewhat critical, On sample 2 condition of critical category land. On sample 3 land conditions are somewhat critical. On sample 4 land conditions is critical, on sample 5 the condition of the soil is very critical and on the sample 6 the land condition is somewhat critical.
\end{abstract}

Key Words: Existence of Nutrients, Critical Land, Alo Watershed

ABSTRAK

Daerah aliran sungai Alo merupakan kawasan konservasi yang secara administrasi geografis berlokasi di Kabupaten Gorontalo yang mencakup tiga kecamatan yaitu kecamatan Limboto Barat, Tibawa dan Pulubala. Penelitian dilakukan dengan tujuan untuk mengetahui eksistensi unsur hara terhadap kondisi lahan di DAS tersebut. Metode yang digunakan yaitu survei lapangan untuk mendapatkan sampel pengujian unsur hara terhadap tanah dan dengan metode pengujian laboratorium yang menggunakan analisa uji gravimetri untuk pengujian kadar air, metode hydrometer untuk pengujian tekstur tanah, metode Walkey-Black untuk pengujian C-Organik, metode Kjeldahl untuk pengujian Nitrogen, Metode Olsen untuk pengujian $\mathrm{P}_{2} \mathrm{O}_{5}$ dan metode Lame Photometer untuk pengujian $\mathrm{K}_{2} \mathrm{O}$. Dari serluruh analisis telah diperoleh informasi bahwa pada sampel 1 dengan kondisi lahan agak kritis, Pada sampel 2 kondisi lahan kategori kritis. Pada sampel 3 kondisi lahan agak kritis. Pada sampel 4 kondisi lahan kritis, pada sampel 5 kondisi lahan sangat kritis dan pada sampel 6 kondisi lahan agak kritis.

Key Words : Eksistensi Unsur Hara, Lahan Kritis, DAS Alo

\section{PENDAHULUAN}

Tanah merupakan media tumbuh untuk tanaman yang bermanfaat bagi ekologis dan biologis suatu lahan. Kondisi lahan sangat dipengaruhi oleh eksistensi tanah tersebut, sebagai contoh dalam taksonomi USDA (1994) disebut bahwa tanah merupakan kumpulan-kumpulan benda alam yang terdapat di permukaan bumi yang mencakup minirel, bahan organik, mengandung benda hidup dan mampu memberikan kehidupan makhluk hidup yang terdapat di permukaan bumi secara umum.

Kondisi Daerah Aliran Sungai secara umum di permukaan bumi terkhususnya di wilayah Indonesia tidak lepas dari eksistensi tanah dan pengelolaan lahan di kawasan tersebut. Kondisi alami suatu DAS, lahan dan tanah saat ini tidak lagi pada semestinya, terdapat banyak faktor yang menjadi pendorong terhadap terjadinya kerusakkan, di antaranya pemanfaatan tanah dan lahan pada kondisi kemiringan lereng lebih dari 15\%, perbukitan menjadi gundul akibat pembukaan lahan, hutan dieksploitasi secara berkala dan berlebihan, perlakuan lahan oleh pihak petani yang tidak mengikuti teknik konservasi.

Kawasan Daerah Aliran Sungai Alo Kabupaten Gorontalo saat ini telah mengalami perlakuan yang sama seperti yang telah dijelaskan pada paragraf di atas. Kondisi DAS tersebut 
telah mengalami pembukaan lahan dibagian perbukitan dan tanaman yang tumbuh secara alami telah digantikan dengan tanaman budidaya seperti, tanaman jagung, pepaya, kelapa, dan jati. Namun secara keseluruhan lahan lebih banyak difungsikan untuk pertanian jagung. Secara umum bahwa jagung tidak boleh ditanam di daerah perbukitan terkecuali dengan menggunakan teknik konservasi. Berdasarkan analisa citra dan peta kemiringan lereng kawasan DAS Alo memiliki morfologi dan kemiringan lereng yang beragam. Untuk kemiringan lereng berkisaran antara 0\%-40\%, dengan kondisi kemiringan lereng tersebut antara 15\%-40\% mampu menjadi faktor utama untuk terjadinya lahan kritis yang diakibatkan hilangnya unsur hara pada tanah di suatu lahan DAS Alo. Berdasarkan grafik persentase jenis pekerjaan masyarakat di DAS Alo di usia kerja dalam penelitian Haspiah 2015, menginformasikan bahwa pekerjaan yang paling dominan adalah petani sebesar 55,6\% dan yang kedua adalah IRT 27\%. Hal ini dapat dianasir bahwa pembukaan lahan dan pemanfaatan lahan di kawasan DAS Alo dapat terjadi lebih besar.

Banyaknya jumlah penduduk petani sangat memungkinkan terjadinya kerusakkan lahan terlebih pada kondisi tanah terhadap lahan kritis. Unsur hara semakin berkurang apabila tidak dilakukan teknik konservasi dalam mengelola lahan secara tenik. Pengeolaan lahan tidak berbasis konservasi akan lebih banyak menimbulkan erosi atau pengikisan tanah pada lahan terbuka. Urgensi dalam penelitian ini adalah melakukan penganalisaan unsur hara pada lahan di kawasan DAS Alo yang dominan mata pencaharian masyarakatnya sebagai petani.

\section{METODE PENELITIAN}

Penelitian dilakukan di kawasan DAS Alo Kabupaten Gorontalo yang secara atministrasi terdapat di tiga kecamatan yaitu kecamatan Limboto Barat, Kecamatan Tibawa dan Kecamatan Pulubala dengan luasan lahan 24.221 Ha.

Proses pengumpulan data peneliti melakukan analisa survei lokasi penelitian dengan mengamati kondisi fisik lahan yang dianasir dalam pendekatan deskriptif dan analisa sintetis kuantitatif yang telah di ansumsikan pada kondisi lahan, kemiringan lereng bentuk morfologi dan kondisi jenis tanah. Jenis data yang digunakan yaitu sifat fisik tanah meliputi analisa unsur hara dengan unsur "N" Nitrogen, "P” Posfor, “K” Kalium, menganalisa unsur kandungan hidrogen atau kadar air dalam tanah dan serta menganalisis tekstur tanah. Pengambilan sampel tanah yang dilakukan yaitu berdasarkan sebaran jenis tanah yang terdapat di kawasan DAS Alo Kabupaten Gorontalo.

Menanganalisis data dilakukan dengan melakukan pengujian laboratorium untuk mengetahui nilai kandungan unsur-unsur yang menjadi parameter tanah meliputi nitrogen, posfort, kalium, dan tektur tanah.

Tabel 1. Kriteria Haisil Penilaian Hasil Tanah

\begin{tabular}{cccccc}
\hline & \multicolumn{5}{c}{ Nilai } \\
\cline { 2 - 6 } Parameter tanah & $\begin{array}{c}\text { Sangat } \\
\text { Rendah }\end{array}$ & Rendah & Sedang & Tinggi & $\begin{array}{c}\text { Sangat } \\
\text { tinggi }\end{array}$ \\
\hline C(\%) & $<1$ & $1-2$ & $2-3$ & $3-5$ & $>5$ \\
N(\%) & $<0,1$ & $0,1-0,2$ & $0,21-0,5$ & $0,51-0,75$ & $>0,75$ \\
C/N & $<5$ & $5-10$ & $11-15$ & $16-25$ & $>25$ \\
P2O5 HCl 25\% (mg 100g $\left.{ }^{-1}\right)$ & $<15$ & $15-20$ & $21-40$ & $41-60$ & $>60$ \\
P2O5 Bray (ppm P) & $<4$ & $5-7$ & $8-10$ & $11-15$ & $>15$ \\
P2O5 Olsen (ppm P) & $<5$ & $5-10$ & $11-15$ & $16-20$ & $>20$
\end{tabular}




\begin{tabular}{|c|c|c|c|c|c|}
\hline \multirow[b]{2}{*}{ Parameter tanah } & \multicolumn{5}{|c|}{ Nilai } \\
\hline & $\begin{array}{l}\text { Sangat } \\
\text { Rendah }\end{array}$ & Rendah & Sedang & Tinggi & $\begin{array}{l}\text { Sangat } \\
\text { tinggi }\end{array}$ \\
\hline 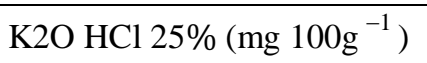 & $<10$ & $10-20$ & $21-40$ & $41-60$ & $>60$ \\
\hline $\mathrm{KTK} / \mathrm{CEC}\left(\operatorname{cmol}(+) \mathrm{kg}^{-1}\right)$ & $<5$ & $5-16$ & $17-24$ & $25-40$ & $>40$ \\
\hline \multicolumn{6}{|l|}{ Susunan kation } \\
\hline $\mathrm{Ca}^{2+}\left(\operatorname{cmol}(+) \mathrm{kg}^{-1}\right)$ & $<2$ & $2-5$ & $6-10$ & $11-20$ & $>20$ \\
\hline $\mathrm{Mg}^{2+}\left(\operatorname{cmol}(+) \mathrm{kg}^{-1}\right)$ & $<0,3$ & $0,4-1$ & $1,1-2,0$ & $2,1-8,0$ & $>8$ \\
\hline $\mathrm{K}^{2+}\left(\operatorname{cmol}(+) \mathrm{kg}^{-1}\right)$ & $<0,1$ & $0,1-0,3$ & $0,4-0,5$ & $0,6-1,0$ & $>1$ \\
\hline $\mathrm{Na}^{2+}\left(\operatorname{cmol}(+) \mathrm{kg}^{-1}\right)$ & $<0,1$ & $0,1-0,3$ & $0,4-0,7$ & $0,8-1,0$ & $>1$ \\
\hline Kejenuhan Basa (\%) & $<20$ & $20-40$ & $41-60$ & $61-80$ & $>80$ \\
\hline Kejenuhan $\mathrm{Al}(\%)$ & $<5$ & $5-10$ & $1-20$ & $20-40$ & $>40$ \\
\hline Cadangan mineral (\%) & $<5$ & $5-10$ & $11-20$ & $20-40$ & $>40$ \\
\hline Salinitas/DHL (dSm-1) & $<1$ & $1-2$ & $2-3$ & $3-4$ & $>4$ \\
\hline $\begin{array}{c}\text { Persentase natrium dapat } \\
\text { ditukar/ESP (\%) }\end{array}$ & $<2$ & $2-3$ & $5-10$ & $10-15$ & $>15$ \\
\hline Sangat Asam & Asam & Agak Asam & Netral & Agak Alkalis & Alkalis \\
\hline $\mathrm{pH} \mathrm{H} 2 \mathrm{O}<4,5$ & $4,5-5,5$ & $5,5-6,5$ & $6,6-7,5$ & $7,5-8,5$ & $>8,5$ \\
\hline
\end{tabular}

Sumber : Balai Penelitian Tanah (2005)

\section{Hasil Analisis Penelitian}

\section{HASIL DAN PEMBAHASAN}

Daerah aliran sungai Alo memiliki kondisi fisik yang menjadi faktor penyebab terjadinya lahan mengalami kekeritisan dan gradasi. Kondisi tersebut dipengaruhi faktor alam yang menjadi komponen utama dalam kesetabilannya. Faktor iklim sangat mempengaruhi keberadaan atau kondisi dari perubahan unsuk tanah dan kandungan kimia maupun fisikanya. Iklim merupakan pengukur yang penting dalam melihat kondisi tanah pada suatu lahan. Keterlibatan unsur iklim yaitu curah hujan, suhu, dan kelembaban dapat mempengaruhi terjadinya peruhan unsur hara yang berdampak pada kekeritisan lahan.

\section{a. Curah Hujan}

Kabupaten Gorontalo terkhusu pada kawasan DAS Alo memiliki curahujan yang cukup fariatif. Dalam enam tahun terakhir diketahui data curah hujan yang meliputi pada tahun 2010 terdapat curah hujan terendah pada bulan maret sebesar $47 \mathrm{~mm}$ dan tertinggi pada bulan mei 336 mm, tahun 2011 terdapat curah hujan terendah pada bulan Agustus sebesar 7 mm dan tertinggi pada bulan Februari 322 mm, tahun 2012 terdapat curah hujan terendah pada bulan September sebesar $46 \mathrm{~mm}$ dan tertinggi pada bulan November $412 \mathrm{~mm}$, tahun 2013 terdapat curah hujan terendah pada bulan September sebesar $37 \mathrm{~mm}$ dan tertinggi pada bulan Mei 308 mm, tahun 2014 terdapat curah hujan terendah pada bulan September sebesar $6 \mathrm{~mm}$ dan tertinggi pada bulan November $321 \mathrm{~mm}$, dan tahun 2015 terdapat curah hujan terendah pada bulan Maret sebesar $46 \mathrm{~mm}$ dan tertinggi pada bulan Mei $188 \mathrm{~mm}$.

\section{b. Suhu dan Kelembaban}

Suhu udara rata-rata berkisar antara maksimum $32,5{ }^{\circ} \mathrm{C}$ sampai dengan minimum 23,3 ${ }^{\circ} \mathrm{C}$ dan rata-rata 6 tahun terakhir mencapai $26,9^{\circ} \mathrm{C}$. Kelembaban udara kategori tinggi dalam enem tahun terakhir memiliki rata-rata $81,1 \%$. 


\section{c. Penggunaan Lahan}

Penggunaan lahan berdasarkan analisa spasial pada peta tutupan lahan meliputi hutan skunder $22 \%$, hutan primer $2,1 \%$, pertanian lahan kering $57 \%$, sawah $1,8 \%$, semak $15,3 \%$, dan pemukiman 0,8\%. Dari data tersebut mengansumsiikan bahwa kawasan DAS Alo untuk tutupan lahan telah didominasi oleh pertanian lahan kering mencapai 57\% dengan luas 13.806,45\% dari total keseluruhan luas lahan DAS. Sehingga dapat diartikan penggunaan lahan oleh masyarakat sangat mempengaruhi terjadinya kondisi lahan menjadi kritis.

\section{d. Vegetasi}

Vegetasi mempunyai peranan penting dalam menjaga keseimbangan ekologi daerah hulu sebagai area konservasi di kawasan DAS Alo. beberapa jenis vegetasi dominan yang tersebar di kawasan DAS Sebagai berikut :

Tabel 2. Jenis Vegetasi Dominan di DAS Alo

\begin{tabular}{|c|c|c|c|c|c|}
\hline No & $\begin{array}{c}\text { Nama } \\
\text { Tumbuhan }\end{array}$ & Bahasa Latin Tumbuhan & No & $\begin{array}{c}\text { Nama } \\
\text { Tumbuhan }\end{array}$ & Bahasa Latin Tumbuhan \\
\hline 1 & Akasia & Acacia tomentosa & 16 & Nanas & Ananas comocus \\
\hline 2 & Bambu & Shizoztachyum sp & 17 & Nangka & Artocarpus heterophyllus) \\
\hline 3 & Cemara & Casuarina sp & 18 & Padi & Oryza sativa \\
\hline 4 & Cokelat & Theobroma cacao & 19 & Paku & Psilophytinae \\
\hline 5 & Damar & Shorea sp & 20 & Palem & Arecaceae \\
\hline 6 & Jagung & Zea mays & 21 & Pepaya & Carica papaya \\
\hline 7 & Jambu Air & Eugenia aquea & 22 & Pinang & Pinangan $s p$ \\
\hline 8 & Jambu batu & Psidium guajava & 23 & Pisang & Musa paradisiaca \\
\hline 9 & Jati & Tectona grandis & 24 & Pisang & Musa paradisiaca \\
\hline 10 & Jeruk nipis & Citrus aurantifolia & 25 & Rambutan & Nephelium lappaceum \\
\hline 11 & Kelapa & Cocos nucifera & 26 & Randu & Ceiba petandra \\
\hline 12 & Kemiri & Dipterocarpus sp & 27 & Salak & (Salacca edulis) \\
\hline 13 & Lamtoro & Leucaena leucocephala ssp & 28 & Tomat & Solanum Iycopersicum \\
\hline 14 & Mangga & Mangifera indica & 29 & Woka & Livistona torundifolia \\
\hline
\end{tabular}

Sumber : Observasi dan Wawancara Warga

e. Kemiringan lereng

Tabel 3. Kelas lereng wilayah DAS Alo

\begin{tabular}{|cccccl} 
No & $\begin{array}{c}\text { Kemiringan } \\
(\%)\end{array}$ & Skoring & \multicolumn{2}{c}{ Luasan } & Keterangan \\
\cline { 4 - 5 } & & & $(\mathrm{Ha})$ & $(\%)$ & \\
\hline 1 & $0-8 \%$ & 1 & 10322,5 & 42,62 & Datar \\
2 & $8-15 \%$ & 2 & 7384,35 & 30,49 & Landai \\
\hline
\end{tabular}




\begin{tabular}{cccccc}
\hline No & $\begin{array}{c}\text { Kemiringan } \\
(\%)\end{array}$ & Skoring & \multicolumn{2}{c}{ Luasan } & Keterangan \\
\cline { 3 - 5 } & & & $(\mathrm{Ha})$ & $(\%)$ & \\
\hline 3 & $15-25 \%$ & 3 & 5364,43 & 22,15 & Agak curam \\
4 & $25-40 \%$ & 4 & 1062,71 & 4,39 & Curam \\
5 & $>40 \%$ & 5 & 85,2091 & 0,35 & Sangat Curam \\
\hline & Total & & $24.221,41$ & $100 \%$ & \\
\hline
\end{tabular}

\section{Sumber : Hasil Analisis}

Berdasarkan tabel 3 di atas menunjukan bahwa DAS Alo memiliki luasan 24.221,41 ha dengan ketingian dan kemiringan lereng yang beragam dimulai dari kemiringan datar (0 - 8 \%), landai (8 - $15 \%)$, agak curam (15 - $25 \%$ ), curam (25 - 40) dan sangat curam (> $40 \%$ ). Dengan demikian dapat dipahami bahwa yang paling dominan kemiringan lereng di DAS Alo yaitu datar dengan luasan lahan mencapai 10.322,5 ha atau 42,62 \% dan paling rendah yaitu kemiringan sangat curam berkisar 85,21 ha atau 0,35 \%.

\section{Pembahasan}

Jenis tanah merupakan faktor yang turut menentukan terjadinya lahan kritis dengan kondisi hilangnya unsur hara dan terkikisnya lapisan organik. Terkikisnya lapisan organik tergantung kondisi kepekaan tanah tersebut dan kepekaan tanah sangat dipengaruhi oleh tekstur dan struktur tanah dalam konsistensinya. Kawasan DAS terdapat enam jenis tanah yatu tanah aluvial, tanah Grumosol, Tanah Andosol, Tanah Podsolik Tanah Litosol, dan tanah Renzina.

Tabel 4. Hasil Analisis Unsur Hara Tanah dan Tingkat Kekeritisan Lahan

\begin{tabular}{|c|c|c|c|c|c|c|c|c|}
\hline \multirow[b]{3}{*}{ No } & \multirow[b]{3}{*}{ Parameter } & \multicolumn{6}{|c|}{ Hasil Analisis Tanah } & \multirow[t]{2}{*}{ Metode } \\
\hline & & Spot 1 & Spot 2 & Spot 3 & Spot 4 & Spot 5 & Spot 6 & \\
\hline & & $00^{0} 38^{\prime} 33,1 \mathrm{U}$ & $00^{0} 40^{\prime} 04,2 \mathrm{U}$ & $00^{0} 41^{\prime} 11,3 \mathrm{U}$ & $00^{0} 42^{\prime} 29,1 \mathrm{U}$ & $00^{0} 43^{\prime} 31,02 \mathrm{U}$ & $00^{0} 40^{\prime} 47,9 \mathrm{U}$ & \\
\hline & & $122^{0} 52^{\prime} 21,9 \mathrm{~T}$ & $122^{0} 50^{\prime} 51,1 \mathrm{~T}$ & $122^{0} 49^{\prime} 38,1 \mathrm{~T}$ & $122^{0} 51^{\prime} 55,3 \mathrm{~T}$ & $122^{0} 51^{\prime} 55,4 \mathrm{~T}$ & $122^{0} 43^{\prime} 28,1 \mathrm{~T}$ & \\
\hline & & Agak Kritis & Kritis & Agak kritis & Kritis & Sangat Kritis & Kritis & \\
\hline 1 & Kadar Air (\%) & 6.50 & 8.70 & 13.12 & 11.61 & 5.04 & 3.31 & Gravimetri \\
\hline 2 & Tekstur & & & & & & & Hydrometer \\
\hline & a. Pasir (\%) & 18.3 & 39.8 & 29.2 & 64.1 & 53.6 & 75.1 & \\
\hline & b. Debu (\%) & 49.3 & 35.7 & 30.7 & 20.2 & 33.8 & 8.3 & \\
\hline & c. Liat (\%) & 32.7 & 24.5 & 40.1 & 15.7 & 12.7 & 16.6 & \\
\hline 3 & C-Organik (\%) & 1.11 & 1.24 & 2.09 & 0.15 & 0.24 & 0.19 & Walkey-Black \\
\hline 4 & N (\%) & 0.12 & 0.04 & 0.21 & 0.04 & 0.03 & 0.06 & Kjeldahl \\
\hline 5 & $\mathrm{P}_{2} \mathrm{O}_{5}(\mathrm{ppm})$ & 210 & 9 & 109 & 13 & 12 & 9 & Olsen \\
\hline 6 & $\mathrm{~K}_{2} \mathrm{O}(\mathrm{ppm})$ & 267 & 63 & 523 & 83 & 78 & 75 & $\begin{array}{l}\text { Flame } \\
\text { Photometer }\end{array}$ \\
\hline
\end{tabular}

\section{Sumber : Data Hasil Analisis Laboratorium}

Berdasarkan pengujian laboratorium bahwa tanah merupakan faktor yang turut 
menentukan terjadinya lahan kritis, tekstur, struktur dan sifat fisik lainya dapat menjadi indikator menurunnya prosuktivitas tanah terhadap lahan. Berdasarkan peta semi detil skala 1:50.000 jenis tanah yang terdapat di DAS Alo Kabupeten Gorontalo meliputi enam jenis tanah yaitu tanah aluvial, tanah andosol, tanah grumosol, tanah litosol, tanah podsolit dan tanah renzina, dan dilakukan analisa survei lapangan untuk mengecek kebenaran data sebagai berikut:

a. Aluvial

Tanah aluvial merupakan tanah muda yang berasal dari hasil pengendapan. Berdasarkan hasil pengamatan tanah alluvial yang terdapat di DAS Alo adalah merupakan tanah hasil dari pengendapan sungai dan aliran permukaan, sehingga banyak ditemui dikawasan pertanian lahan basah seperti sawah dan rawa sungai. Tanah aluvial yang di jumpai di lokasi penelitian memiliki epipedon yang berwarna coklat gelap atau coklat tua. Pengambilan sampel tanah aluvial dilakukan di perkebunan jagung tepat di desa Isimu Selatan dengan koordinat $00^{0} 38$ '33,10 U dan $122^{0} 52^{\prime 2} 21.90$ T. Sifat tanah aluvial berdasarkan pengamatan solum atau kedalaman efektif lebih dari $96 \mathrm{~cm}$ atau kategori dalam dan memiliki tekstur liat debu berpasir dengan memiliki nilai $\mathrm{N}$ yaitu 0,12\%, nilai $\mathrm{P}_{2} \mathrm{O}_{5}$ sebesar $210 \mathrm{ppm}$ dan nilai $\mathrm{K}_{2} \mathrm{O}$ sebesar 267 ppm. Memiliki tekstur pasir 18.3\%, debu 49,3,7\% dan liat 32,7\%, dari analisis tersebut maka kondisi tanah berkategori agak kritis.

b. Grumosol

Tanah grumusol terbentuk dari pelapukan batuan kapur dan tuffa vulkanik. Kandungan organik di dalamnya rendah karena dari batuan kapur jadi dapat disimpulkan tanah ini tidak subur dan tidak begitu cocok untuk ditanami tanaman. Berdasarkan hasil analisi labolatorium pada tabel 4. bahwa tanah ini memiliki nilai $\mathrm{N}$ yang cukup rendah yaitu $0,04 \%$, nilai $\mathrm{P}_{2} \mathrm{O}_{5}$ sebesar 9 ppm dan nilai $\mathrm{K}_{2} \mathrm{O}$ sebesar 63 ppm. Memiliki tekstur pasir 39,8\%, debu 35,7\% dan liat 24,5\%. Hal tersebut menunjukan tekstur lebih dominan pasir dan dari analisis tersebut maka kondisi tanah berkategori kritis. Pengambilan sampel tanah grumosol di lakukan di desa Botumoputih Kecamatan Tibawa yang masih merupakan wilayah DAS Alo.

c. Andosol

Jenis tanah ini pada dasarnya tanah yang berkembang dari bahan vulkanik seperti abu vulkan, batu apung, sinder, lava dan atau bahan vulkanolistik yang fraksi koloidnya di dominasi oleh mineral non kristalin. Janis tanah andosol tersebar di dua kecamatan Tibawa dan Pulubala dan merupakan jenis tanah yang paling luas yang tersebar di DAS Alo. Berdasarkan hasil observasi lapangan pada lampiran 3 tanah ini berwarna hitam kecoklatan, dan memiliki kedalam efektif $88 \mathrm{~cm}$ yang berarti memiliki kategori agak dalam. dan memiliki tekstur liat debu berpasir, sesuai analisis uji laboratorium pada tabel 4, tanah andosol yang terdapat di DAS

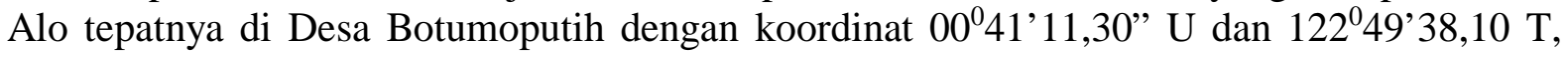
bahwa persentase tekstur yaitu liat 40,1\%, debu 30,1\% dan pasir 29,2\%. Hal tersebut menunjukan bahwa lebih dominan liat dibandingkan dengan pasir dan dari analisis tersebut maka kondisi tanah berkategori agak kritis. Tanah ini sangat kaya dengan mineral, unsur hara, air dan mineral sehingga sangat baik untuk tanaman. Pengambilan sampel tanah terdapat disekitar penggunaan lahan meliputi perkebunan kelapa dan jagung.

d. Podsolik

Tanah ini bewarna merah hingga kuning dan kandungan organik serta mineralnya akan sangat mudah mengalami pencucian oleh air hujan. Oleh karena itu untuk menyuburkan tanah ini harus ditanami tumbuhan yang memberikan zat organic untuk kesuburan tanah serta pupuk baik hayati maupun hewani. Tanah podsolik yang terdapat di DAS Alo merupakan tanah yang dimanfaatkan untuk penanaman jagung, namun hasil pengamatan menyatakan bahwa tanah tersebut mengalami erosi akibat aliran permukaan, tekstur berpasir krikil. Hasil analisis manyatakan bahwa tanah podsolik termasuk dalam kategori lahan kritis, dengan kadar air 11,61\%. Unsur hara menunjukan sudah kritis hal tersebut dapat diketahui dari nilai $\mathrm{N}$ hanya 
0,04 \%, nilai $\mathrm{P}_{2} \mathrm{O}_{5}$ sebesar 13 ppm, dan $\mathrm{K}_{2} \mathrm{O}$ sebesar 83 ppm. Kedalaman efektif hanya $13 \mathrm{~cm}$ dengan keadaan tekstur pasir debu berliat.

e. Litosol

Pada dasarnya tanah litosol merupakan tanah yang baru mengalami perkembangan dan merupakan tanah yang masih muda. Terbentuk dari adanya perubahan iklim, topografi dan adanya vulkanisme. Karakteristik tanah litosol yang terdapat di DAS Alo merupakan tanah litosol yang berpasir dan merupakan tanah muda yang baru mengalami pelapukan dari batuan, sehingga memungkinkan tanah ini sangat kritis akan unsur hara. Hasi analisis labolatorium menunjukan bahwa tanah ini memiliki kadar air yang relatif kecil yaitu 5.04\%. tekstur tanah pasir debu berliat, dimana persentasi pesir sebesar 53,6\%, debu 33,8\% dan liat yang relatif sedikit yaitu sebesar $12,7 \%$. Selain hal tersebut unuk analisis unsur hara juga menunjukan bahawa nilai $\mathrm{N}$ hanya $0,03 \%$, nilai $\mathrm{P}_{2} \mathrm{O}_{5}$ sebesar $12 \mathrm{ppm}$, dan $\mathrm{K}_{2} \mathrm{O}$ sebesar 78 ppm. Berdasarkan data lapangan pada lampiran 5, warna tanah menunjukan warna kecoklat kuningan, tanah ini memiliki kedalaman efektif $11 \mathrm{~cm}$ kategori dangkal, hal tersebut menunjukan bahwa lapisan top soil sangat tipis sehingga mengakibatkan tanah tidak lagi produktif.

f. Renzina

Tanah jenis ini memiliki kandungan Ca dan Mg yang cukup tinggi, berwarna coklat kekuningan serta hanya mengandung sedikit unsur hara. Hasil pengambilan sampel menunjukan tanah rendzina yang terdapat di DAS Alo dengan koordinat $00^{\circ} 40^{\prime} 47.9^{\prime \prime} \mathrm{U}$ dan 122 ${ }^{\circ} 43^{\prime 28.1 " T ~ m e n u n j u k a n ~ t e r m a k s u d ~ k a t e g o r i ~ t a n a h ~ k r i t i s, ~ k e d a l a m a n ~ e f e k t i f ~} 11 \mathrm{~cm}$ termaksud criteria dangkal. Dengan tekstur tanah pasir liat berdebu, dominan pasir mencapai $75,1 \%$ debu 8,3\% dan liat mencapai 16,6\%. Dengan kadar air yang sangat rendah yaitu 3,31\%. Unsur hara ditununjukan berdasarkan nilai $\mathrm{N}$ hanya $0,06 \%$, nilai $\mathrm{P}_{2} \mathrm{O}_{5}$ sebesar $9 \mathrm{ppm}$, dan $\mathrm{K}_{2} \mathrm{O}$ sebesar 75 ppm.

\section{KESIMPULAN}

Hasil analisis pengujian laboratorium pada 6 sampel yang mewakili setiap jenis tanah dengan metode pengujian yang menggunakan analisa uji gravimetri untuk pengujian kadar air, metode hydrometer untuk pengujian tekstur tanah, metode Walkey-Black untuk pengujian COrganik, metode Kjeldahl untuk pengujian Nitrogen, Metode Olsen untuk pengujian $\mathrm{P}_{2} \mathrm{O}_{5}$ dan metode Lame Photometer untuk pengujian $\mathrm{K}_{2} \mathrm{O}$ telah diperoleh informasi bahwa pada sampel lokasi 1 dengan koordinat $00^{\circ} 38^{\prime} 33,1$ LU dan 122 $52^{\prime} 21,9$ BT kondisi lahan agak kritis. Pada sampel lokasi 2 dengan koordinat $00^{\circ} 40^{\prime} 04,2$ LU dan 122 ${ }^{\circ} 50^{\prime} 51,1$ BT kondisi lahan kategori

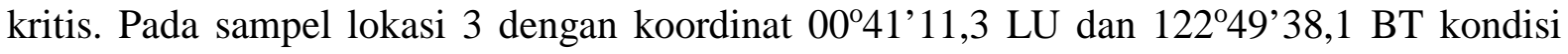
lahan agak kritis. Pada sampel lokasi 4 dengan koordinat 00²'’29,1 LU dan 12251'55,3 BT

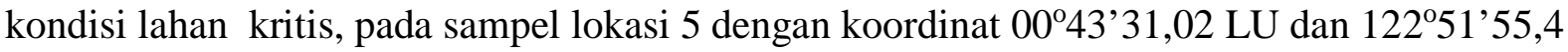
BT kondisi lahan sangat kritis dan pada sampel loasi keenam dengan koordinat 0040'47.9"U LU dan $122^{\circ} 43^{\prime 28.1}$ BT pada kondisi lahan agak kritis.

\section{DAFTAR PUSTAKA}

Arsyad, S. 2010. Konservasi Tanah dan Air. Edisi Kedua. Pustaka IPB. Press. Bogor Banua, I.S. 2013. Erosi. Kencana. Jakarta

Kartasapoetra, 2000. Teknologi Konservasi Tanah dan Air. Reneka Cipta. Jakarta.

Lihawa, F. 2011. Konservasi dan Reklamasi Lahan. Reviva Cendekia. Universitas Negeri Gorontalo

Morgan, 2005. Soil Erosion \& Conservation. Third Edition. Blackwell Publishing. Australia 